\title{
The Implication of "Ewuh Pakewuh" Cultural in OCB Implementation of Service Employee at Pesantren Sub District of Kediri City
}

\author{
Restin Meilina ${ }^{1}$, Dodi Kusuma Hadi Soedjoko ${ }^{2}$ \\ \{restin@unpkediri.ac.id ${ }^{1}$, dodikusuma@webmail.unpkediri.ac.id ${ }^{2}$ \} \\ ${ }^{1,2}$ Nusantara PGRI Kediri University, Indonesia
}

\begin{abstract}
Organizational citizenship behavior (OCB) is very important in improving organizational performance. Many factors can influence OCB, one of which is organizational culture. The purpose of this study is to find out how the implications of "ewuh pakewuh" cultural that still attached to the Indonesian bureaucracy in the OCB implementation. This study uses a qualitative approach with descriptive techniques. The results showed that five of the nine dimensions of "ewuh pakewuh" culture caused a decrease in the dimensions of sportsmanship, courtesy, and conscientiousness in the OCB implementation of service employee at Pesantren sub-district of Kediri city.
\end{abstract}

Keywords: Organizational culture, ewuh pakewuh, organizational citizenship behavior.

\section{Introduction}

After the enactment of a new brand "Harmony Kediri The Service City" in mid-2016, every government agency in Kediri city continuous to strive in improving the quality of its public services. This effort to show its commitment as the service city that must be ready to provide excellent service for every citizen. The process of improving the quality of its service is carried out quickly, including physical and non-physical facilities and also service employee. One of the agencies in Kediri that made a significant change was the pesantren subdistrict.

Since the end of 2016, the pesantren sub-district of Kediri City has made changes to support the improvement of the public services quality. The office is more comfortable and equipped with air conditioners, TVs, and refrigerators with a variety of foods and drinks. The service flow that used to seem long and convoluted nowadays has become easier and can even be accessed online. To improve the quality of service employees, pesantren sub-districts routinely provide training such as public service ethics, excellent service through social media, and similar training. All these efforts will not achieve optimal results if there is no strong motivation from service employees to change. It is useless in repairing facilities or training if there is nothing employee's intention to make changes.

The success of "Harmony of Kediri The Service City" brand, must be supported by organizational citizenship behavior (OCB) from service employees. Service employees must have a higher performance than other employees. If other employees arrive at the latest at 8 am, the service employee must arrive early to prepare all the service needs so that no citizen who needs services has to wait long. In the rest time, service employees must take turns and cannot rest too long because the service at Pesantren sub-district office is always open without a break. Service employees must also be prepared to answer questions and complaints from 
the citizen in the Pesantren sub-district social media without time limits, even service employees often do not take their leave of absence (holiday rights) because there is no substitute employee. The service employee must always show a good attitude, polite, and friendly regardless of his mood and whoever is served. Service employees are the spearhead for the progress of an organization. OCB shows the behavior of employees who make big individual contributions to support the achievement of organizational performance [1] and also positive and constructive social behavior [2]. Several studies about OCB and service quality show that OCB has a significant positive effect on service quality [3], [4].

The researcher has conducted preliminary research related to OCB at the pesantren subdistrict office in 2017 with the title "Optimization of OCB to Improve the Public Services Quality in Kediri City" [5]. The results of the study show that service employees at the pesantren sub-district have implemented OCB, but there are only a few aspects that must be optimized. Many things affect OCB implementation, one of which is organizational culture. The research of Yohanas Omar in 2013 showed that organizational culture had a significant effect on OCB [6]. One organizational culture in the bureaucracy (government) that is quite entrenched is the "ewuh pakewuh" culture. This culture is quite strong in Java. "Ewuh pakewuh" show reluctance or reluctant towards seniors or superiors, giving rise to pressure or urgency feelings [7]. The "ewuh pakewuh" culture may force service employees to carry out all change programs from pesantren sub-districts that showing unoptimized OCB implementation. OCB should be based on voluntary behavior, not because of coercion. The dynamics of "ewuh pakewuh" in the government has made the government unable to show optimal performance [8], in Usman and Ari Kuncara Widagdo's research showed that "ewuh pakewuh" had a negative effect on the effectiveness of government internal audits. This is because in the "ewuh pakewuh" culture there is a misalignment of attitudes and behavior due to feelings of reluctance.

Based on the description above, the researcher is interested in conducting research related to how the implication of "ewuh pakewuh" culture in OCB implementation of service employee at Pesantren sub-district of Kediri city. The purpose of this research is to find out whether the "ewuh pakewuh" culture provides implication for OCB implementation of service employee at Pesantren sub-district of Kediri city. The results of this study are expected to be useful for evaluating the performance of service employees in the pesantren sub-district of Kediri city and ultimately the OCB of employees can be optimized.

\section{Literature Review}

\subsection{Organizational Citizenship Behaviour (OCB)}

OCB is a voluntary extra-role behavior without considering direct compensation or performance achievement rewards [1]. For organizations, OCB of the employee is very important because it shows the implementation of work that exceeds responsibility so that it shows high performance and supports the performance improvement of the organization. Dennis Organ in 1988 described the five dimensions of OCB consist of altruism that showing voluntary behavior to help colleagues for complete their tasks, civic virtue that demonstrating voluntary behavior fully participating in organizational functions, conscientiousness that showing voluntary behavior to deliver performance beyond standards, courtesy that showing voluntary behavior to alleviate the problems faced by others, and sportsmanship shows voluntary behavior to uphold the good name of the organization.

In service employees in the sub-district pesantren of Kediri city, OCB is indicated by replacing coworkers who take a rest or absent and also help the problems faced, would be 
arrive early and go home at the latest, didn't take extra time for leave in holiday rights (10 days a year), fully involved in organizational policies, functions and activities even ready to follow the developments and changes needed in the organization. The dimensions that are lacking and need to be improved are the dimensions of sportsmanship because there are often complaints or swear from employees [5].

\section{2 "Ewuh Pakewuh" Culture}

The "ewuh pakewuh" culture is one of the strong cultures in Indonesia, especially in Java island. "Ewuh Pakewuh" shows discomfort feeling, reluctant, awe, and upholds respect for others [9]. This feeling usually arises because of differences in seniority, age, and because they already know or receive a lot of kindness from that person. To measure the cultural value of "ewuh pakewuh" some researchers combine the cultural dimensions of Hofstede (1980) and Schwartz (1994) to form nine dimensions consist of individualism, power distance, uncertainty avoidance, masculinity, mastery, harmony, embeddedness, autonomy, and professionalism [9].

Fatmawati research [7] found that "ewuh pakewuh" occurs when low individualism, high power distance, high uncertainty avoidance, low masculinity, low mastery, low harmony, high embeddedness, low autonomy, and low professionalism. In this study, the researcher used these nine criteria to find out the implication of "ewuh pakewuh" culture in OCB implementation of service employees at Pesantren sub-district of Kediri city.

\section{Methodology}

This study uses a qualitative approach with descriptive techniques. The data were taken in Pesantren sub-district of Kediri city by observing and interviewing all three service employees in April - May 2019. Pesantren sub-district was chosen because there was an interesting phenomenon in which the three service employees had a long different age range. The First informant was 42 years old, the second informant was 33 years old, and the third informant was 19 years old. The age range is very possible for the "ewuh pakewuh" culture because one of the drivers of this culture is the age difference [7]. The collected data is then analyzed through the process of reduction, digestion, and extraction.

\section{Result and Analysis}

\subsection{Individualism Implication in OCB Implementation}

The "ewuh pakewuh" culture is indicated by low individualism. In this culture, someone will feel discomfort if only thinking for himself. Low individualism shows higher togetherness even though sometimes it caused forced feeling. The results of interviews with 3 informants all stated that in the service department, no one thought of individual benefits. One example is when they want to absent or take holiday rights during school holidays to be able on vacation with their family, they admitted that they felt reluctant and discomfort feeling because it would be troublesome for his coworkers. This feeling shows the existence of "ewuh pakewuh" that sometimes trigger complaints so that it reduces the sportsmanship dimension in OCB. Those complaints usually occur when there is a conflict of interest between personal interests and "ewuh pakewuh" with coworkers.

\subsection{Power Distance Implication in OCB Implementation}


High power distance can strengthen the culture of "ewuh pakewuh" where someone acknowledges the existence of a clear difference in position and realizes that the boss has the right to privilege. This feeling makes a person not have the choice to reject the boss's orders even if they are against his conscience. The results of researcher observations in the service department, power distance is quite low. The head of the service department is younger than one of the employees so it must apply a loose leadership style. They feel more as a team than their superiors and subordinates. The interview also shows the consistency according to these observations that there are no "ewuh pakewuh" superiors and subordinates. They criticize each other and also accept criticism. This shows the civic virtue dimension in OCB where employees regulate togetherness, support and strive to improve organizational functions.

\subsection{Uncertainty Avoidance Implication in OCB Implementation}

Uncertainty leads to high risk. Facing high uncertainty makes one surrender to the decision of the boss. High uncertainty avoidance can make a person tend to be passive, fully dependent, and follow the decision of the boss even if it is contrary to his heart. This shows the culture of "ewuh pakewuh". The results of the interview indicated that 2 of the 3 informants stated that they often felt this. For example, when there is a problem experienced by coworkers, the two informants tend to wait for the decision of the boss rather than immediately thinking of a solution. They are reluctant if those solutions will have a bad impact on their coworkers. This "ewuh pakewuh" culture can reduce the courtesy dimension in OCB where courtesy shows voluntary behavior to alleviate problems faced by others.

\subsection{Masculinity Implication in OCB Implementation}

Masculinity shows a person's effort to accentuate himself in the organization. The "ewuh pakewuh" culture is shown by low masculinity in which someone feels discomfort if he becomes superior to others so there is no effort to accentuate him. The results of the interview indicated that one of the informants stated that he often felt the lack of masculinity. Based on the awareness that his age is still very young and his status just an honorary employee, make he felt "ewuh pakewuh" if he considered better than other coworkers so there is no effort to show his achievements. This decreases the conscientiousness dimension in OCB where conscientiousness shows voluntary behavior to show performance and prerequisites that exceed minimum standards.

\subsection{Mastery Implication in OCB Implementation}

Mastery shows someone's efforts to master or change the social environment for personal or group interests. The "ewuh pakewuh" culture is shown by the tendency of a low mastery where someone is reluctant to make changes in his social environment because of fears of rejection or disappointment in others and the risk of uncertainty. The results of the interview showed that all informants had no "ewuh pakewuh" in making changes. They are ready to work together to make changes in systems, procedures, and service facilities regardless of the risks that must be faced. This shows the optimal dimensions of the civic virtue in OCB without being affected by the "ewuh pakewuh" culture. 


\subsection{Harmony Implication in OCB Implementation}

Harmony shows an effort to maintain a balance in the work environment. The "ewuh pakewuh" culture in harmony is indicated by efforts to maintain harmony in the organization even though it must harbor negative problems or feelings that they felt. The results of the interview indicated that the three informants sometimes harbor their resentment at their coworkers because of "ewuh pakewuh" that must maintain harmony. This "ewuh pakewuh" culture implies a decrease the sportsmanship dimension in OCB where informants sometimes have to share their complaints with their closest family to maintain their mood so they don't get worse when working.

\subsection{Embeddedness Implication in OCB Implementation}

Embeddednes shows the bound of someone in a group. The "ewuh pakewuh" culture is indicated by high embeddedness where a person feels bound to his group so that he must do everything important to the group even if it is against his heart. The results of the interview indicated that all informants felt a high level of embeddedness in the service department. One example is the agreement that the rest time should be done as soon as possible just to pray and lunch because they have to take turns with other coworkers. This makes each informant feel "ewuh pakewuh" when he wants to spend a long time to rest. The implication of this "ewuh pakewuh" culture is the increasing dimension of altruism in OCB where altruism shows voluntary behavior to help other employees. However, this can also have an impact on the decline in the sportsmanship dimension in OCB when employees complain about their reduced time privacy in the interest of the group.

\subsection{Autonomy Implication in OCB Implementation}

Autonomy shows how someone is motivated to show their creativity, perspective, and ideas for the organization. The "ewuh pakewuh" culture shows a low autonomy in which a person tends to follow and obey the decision of the boss even though it is not in accordance with his ideas and perspective. The results of interviews related to the autonomy aspect as well as the power distance aspect showed that all informants were ready to criticize, accept criticism, and exchange ideas for the improvement of the organization. This shows the consistency that in the service department of Pesantren sub-district the civic virtue dimension in OCB is already strong and not affected by the "ewuh pakewuh" culture.

\subsection{Profesionalism Implication in OCB Implementation}

Professionalism shows a person's ability to make decisions through rational consideration. The "ewuh pakewuh" culture encourages a low level of professionalism whereby someone feels uncomfortable with their boss so they cannot make rational considerations and follow whatever the decision of the boss. The results of the interviews all the informants stated that they always use rational considerations when making decisions without feeling uncomfortable with their superiors. Even if needed, they will criticize their superiors for the progress of the organization. This is a manifestation of the civic virtue dimension in OCB that is not influenced by the "ewuh pakewuh" culture. 


\section{Conclusion}

The result of this study can conclude that the "ewuh pakewuh" culture which gives implication to the OCB implementation of service employees at Pesantren sub-district of Kediri city are low individualism, high uncertainty avoidance, low masculinity, low harmony, and high embeddedness. These five cultural dimensions of "ewuh pakewuh" have an impact on the decline in the dimensions of sportsmanship, courtesy, and conscientiousness in OCB. For high embeddedness dimensions, although it reduces the sportsmanship dimension in OCB, it can improve the dimensions of altruism in OCB. One of OCB's strong implementation in the service department of Pesantren sub-district of Kediri city is the civic virtue dimension. Implementation of this civic virtue dimension is not influenced by the "ewuh pakewuh" culture in power distance, mastery, autonomy, and professionalism

Based on these results, OCB of service employees at Pesantren sub-district can be optimized by paying attention to the "ewuh pakewuh" culture that influences it. Plans for further research will be developed by adding research objects and subjects or using other research methods.

\section{References}

[1] M. Darto, "Peran Organizational Citizenship Behaviour (OCB) dalam Peningkatan Kinerja Individu di Sektor Publik: Sebuah Analisis Teoritis dan Empiris," J. Borneo Adm., vol. 10, no. 1, pp. 10-34, 2014.

[2] J. Badruzaman, "Pengaruh Budaya Organisasi dan Organization Citizenship Behaviour (OCB) Terhadap Kualitas Layanan ( Studi kasus pada Rumah Sakit Umum Daerah Kota Tasikmalaya )," J. Akunt., vol. 7, no. 1, pp. 66-91, 2012.

[3] S. P. Djati, "Variabel Anteseden OCB dan Pengaruhnya terhadap Service Quality pada PTS di Surabaya," J. Apl. Manaj., vol. 7, no. 3, pp. 782-735, 2008.

[4] R. Meilina and M. W. Widodo, "Kepuasan Kerja, Komitmen Organisasi, Organizational Citizenship Behaviour (OCB) dan Pengaruhnya Terhadap Kualitas Pelayanan Publik," JIBEKA, vol. 11, no. 1, pp. 49-57, 2017.

[5] R. Meilina and M. W. Widodo, "Optimalisasi Organizational Citizenship Behaviour (OCB) Untuk Meningkatkan Kualitas Pelayanan Publik di Kota Kediri," in Prosiding Seminar Nasional Riset Manajemen dan Bisnis SANSETMAB 2017 "Perkembangan Konsep dan Riset E-Business di Indonesia," 2017, pp. 942-953.

[6] Y. Oemar, "Pengaruh Budaya Organisasi, Kemampuan Kerja dan Komitmen Organisasi terhadap Organizational Citizenhsip Behavior (OCB) Pegawai pada BAPPEDA Kota Pekanbaru," J. Apl. Manaj., vol. 11, no. 1, pp. 65-76, 2013.

[7] R. Fatmawati, "Budaya Birokrasi Ewuh Pakewuh Dan Kecurangan Akuntansi Di Pemerintahan: Persepsi Aparat Pengawas Internal Pemerintah (APIP) Inspektorat Kabupaten Sragen," J. Aktual, vol. 2, no. 1, pp. 20-33, 2016.

[8] Usman and A. K. Widagdo, "Pengaruh Independensi dan Budaya Ewuh Pakewuh terhadap Efektivitas Audit Internal Pemerintah," 2015, pp. 370-380.

[9] H. I. Soeharjono, "Pengaruh Budaya Birokrasi 'Ewuh Pakewuh' terhadap Efektivitas Sistem Pengendalian Intern,” J. Ilmu Adm., vol. VIII, no. No. 3, pp. 243-361, 2011. 